\title{
The Formation of Food Cluster in Indonesia
}

\author{
Donald Crestofel Lantu ${ }^{1}$, Sri Herliana ${ }^{2 *}$, Mia Rosmiati ${ }^{1}$, Qorri Aina ${ }^{1}$, Nur Lawiyah ${ }^{1}$ \\ ${ }^{1}$ Institut Teknologi Bandung, School of Business and Management, Bandung, Indonesia \\ ${ }^{2}$ Institut Teknologi Bandung, School of Life Sciences and Technology, Bandung, Indonesia
}

\begin{abstract}
Cluster has an important role in developing the existing resources in an area to be economic value. Companies gain competitive advantage through competing with each other. However, there is now an increased awareness that to ensure survival, it is necessary to balance industrial advocacy and personal interests. Thus, cluster operations are characterized by competition and cooperation, where the role of quadruple helix plays a role in it. SME clusters occur in every country, considering that SMEs are an important element in the economy of the country. Most SMEs in developing countries are located in industrial clusters. Despite the limitations in organizational resources and capacity, the grouping of companies in geographic proximity is capable of improving the performance of the companies within them. Therefore, cluster formation becomes the main attraction for deeper examination, how clusters are formed and how the process and role of elements in it. This study involves two different case studies of the chips and milk dairy clusters, both located in Cimahi, West Java. West Java is one of the provinces that have potential in the development of food and beverage clusters. This research uses qualitative data approach and supported by literature data support. From the analysis result, both clusters have different cluster forming approach, where the formation of clusters of chips, formed spreads and dairy cluster vertically.
\end{abstract}

\section{Introduction}

West Java province has potential in the growth of SMEs food-based cluster. Thus, West Java has become one of the government's priorities in developing food clusters [1]. Clusters play an important role in the competitive process in business, where group resources affect the company's internal resources [2]. Among them are increasing the credibility of the company, the products, and the provision of access to the market. Thus, establishing a fair and supportive trade in market information research [3]. The development of successful industrial clusters can be likened to art and science, where the human relationship in it symbolized with art. The symbol of science represents an analysis of industry data available for making key decisions [4]. Cimahi is one city in West Java which has Human Development Index is above the average of West Java province. However, one component of the Human Development Index is the ability of purchasing power turned out to have a low score.

Therefore, the local government is pursuing a strategy of local economic development potential to expand the purchasing power of the pro-poverty [5]. Strategy of local economic potential development by local government is by developing cluster of SMEs in accordance with the existing potential. There are four clusters were developed, namely the food and beverage industry clusters, textile industry and textile products clusters, handicraft industry cluster, and telematics industry cluster. As mentioned before, the potential of West Java is one of them is in the food and beverage industry cluster. Therefore, researchers further examined the case study of food and beverage clusters in Cimahi as the main focus of this study. In this study, researchers examined two types of industrial and food clusters, namely industrial clusters chips in the Pojok Cimahi and dairy cow industry clusters in Cipageran Cimahi. Researchers focused the research area on the process of establishing food and beverage industry clusters, which could represent the process of clustering SMEs in Indonesia. Due to the cluster formation model can help to succeed the local potential economic development strategy.

\section{Literature Review}

\subsection{Forming cluster}

Companies gain competitive advantage through competing with each other. However, there is now an increased awareness that to ensure survival, it is necessary to balance industrial advocacy and personal interests. Thus, cluster operations are characterized by competition and cooperation. Where the role of quadruple helix plays a role in it [6]. Policy-based SME cluster formation has been implemented by the Government of Indonesia since the 1970s. Aims to improve their competitiveness; as SMEs become an important engine for national growth $[7,8]$. In the phase of cluster

\footnotetext{
* Corresponding author: sri.herliana@sbm-itb.ac.id
} 
formation and growth, where the growth phase consists of 4 phases including agglomeration, emerging, developing, and mature. Transformation can happen anytime, either when a cluster is formed or when it matures. Even the possibility of cluster to disperse always exist in various phases [9]. Each country has a different formation of the cluster initiative. This is due to differences in regional policy, the role of state agencies, and the function of the cluster itself [10]. Government policy is required to perfect existing clusters or develop newly emerging clusters. Adaptation of policies tailored to the important cluster character is done, due to the unique character of the cluster, so universal implementation of the policy cannot be done. There are five most common types of cluster policies that can be applied and adapted, namely; mediation policy, policy of demand stimulation, educational policy, policy of stimulation of external connections, and policy of creation of favorable structural conditions [10]. Based on Tambunan (2005) study, there are four cluster types in Indonesia that is 2rtisanal, active, dynamic, and advanced. Where the type of 2 rtisanal is a cluster consisting of Micro enterprises and has limitations in resources. The active type is a cluster consisting of SMEs with expertise and using better technology than the artist type. The dynamic type is a cluster consisting of SMEs that have a wide trading network, have adequate expertise and technology. The advanced type is a cluster type that has been stable in every line of business and form of cooperation and market [11].

\subsection{SME's Food and Beverage cluster}

Most SMEs in developing countries are located in industrial clusters. Despite the limitations in organizational resources and capacity, the grouping of companies in geographic proximity is capable of improving the performance of the companies within them [8, 12]. Much literature discusses that food and beverage clusters are very closely related to geographic and local potential. In which key organizations are formed to manage and develop clusters [6] As mentioned earlier, the formation of food and beverage clusters can be one of the strategies to improve people's purchasing power. Where in its development can help reduce the poverty rate [5]. Industry clusters stimulate and enable innovation [13], certainly in it there is the product commercialization process. Where the commercialization process requires a lot of strategic marketing activities and decisions and related tactics, it takes a driving force that comes from innovation and understanding of their activities in choosing decisions [14]. The formation and development of clusters cooperate with local government bodies. Including for food and beverage industry clusters, where government agencies and private institutions are adapted to the needs of clusters [15].

\section{Methodology}

The purpose of this research is to know and analyze how food and beverage clusters are formed. Therefore, this study uses a double case study of two clusters in Cimahi, including the chips cluster in the Pojok and the milk dairy cluster at Cipageran. In collecting the data, the researcher used a qualitative data [16] approach obtained from the in depth unstructured interviews to the SMEs in these two clusters. Secondary data support is obtained from various journals, books, and government agency reports. The selection of these two clusters as primary data sources is due to differences in the process of cluster formation. Especially these two clusters are in the same area, namely Cimahi City.

\section{Analysis and Discussion}

\subsection{Chips's Cluster}

Pojok Cimahi is famous as the industrial center of chips. The advantages of chips products produced and sold in this cluster include a wide selection of products, variety of raw materials used, taste choices offered, and affordable and competitive prices. The initial formation of clusters in this cluster is motivated by the success of one SME which is their neighbor. These successful SMEs motivate neighbors to create the same business by imitating its business processes. Although they imitate their business processes, every SME in this cluster is doing a little bit of innovation in its business processes. Thus, they have different target markets as well as with products that are made, due to adjusting to their target market. Based on the data collected and the results of the analysis, it is known that the process of forming this cluster formed by spreading see one of successful SMEs in this cluster. The formation of this naturally chips cluster invites quadruple helix to contribute to the development of clusters. Figure 1 illustrates the process of cluster formation in the chips cluster at Pojok Cimahi.

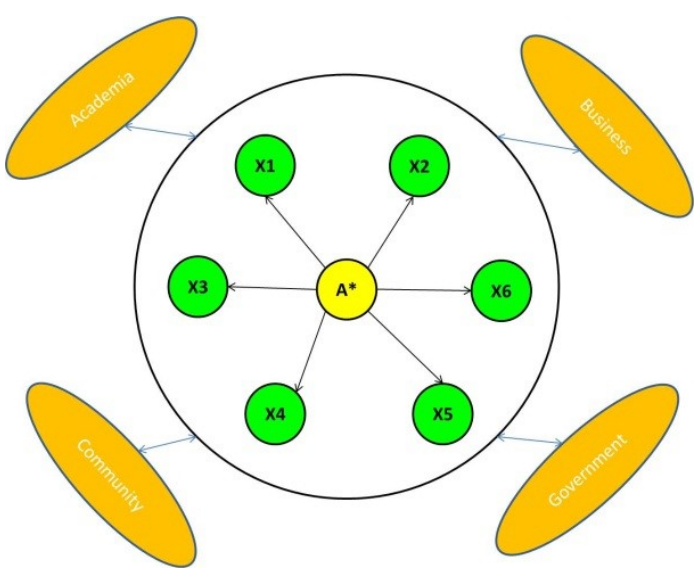

Fig. 1. Model of chips cluster formation in Pojok

Figure 1 illustrates the process of forming the chips cluster in the Pojok Cimahi is spread. Where SME A is portrayed as a successful pioneer of business chips, then neighbors of the surrounding are tempted to do the same business and succeed. Viewed from the cluster type that is formed as described in the study Tambunan (2005), this chips cluster is included in the category of 
active cluster type, where in this cluster involves specific expertise and the use of technology. The skills required in this type of business are expertise in production and research and development product. Where the use of technology required is for the field of production and marketing. This naturally occurring cluster, invites quadruple helix to give their respective roles directly to the cluster, where the role of government gives its policy to help this cluster develop well. Academia provides a role in the form of training in production and marketing development as well as providing consulting services. The existence of this cluster provides widespread opportunities for cooperation with other business lines, such as raw material suppliers and marketing dealers. The last role of the community is to help introduce the name of Pojok Cimahi as the center of chips industry in Cimahi. The appropriate policy to be applied in this cluster is policy of demand stimulation policy, because this cluster has shaped its market and create stable market demand [10].

\subsection{Dairy Milk’s Cluster}

Just like the previous explanation of the Pojok Cimahi cassava chips cluster, the Cipageran milk cluster may be called a cluster because in it there are many dairy farmers and dairy business groups, which produce a wide variety of dairy-based products, such as milk's soap, milk's chips, milk's seroja, milk's rangginang, milk's dodol, caramel candy, yoghurt, and other products. It cannot be separated from the role of government in seeing the huge potential that this cluster possesses. Together with educational institutions, the government is working together to train the housewives to be made a dairy group, where one of the training coaches finally went directly to the cluster development process in the form of opening a Cipageran milk center store. This store has a role in collecting products of business groups and independent in selling dairy products that will be marketed by this store. In contrast to the cimahi Pojok cassava chips cluster, where cluster formation is formed on personal initiative, this cluster of Cipageran milk centers is formed on the basis of the role of government, educational institutions, and private institutions. Thus, the existence of this Cipageran milk cluster can provide added value to housewives including skill and additional income. For farmers and local people have the advantage that this cluster is more famous because there are many activities that live in it.

The initial formation of this cluster is based on the existing potential of dairy cow breeding potential that produces cow's milk. Nevertheless, the potential of this area cannot be maximized to be named as a cluster, due to the lack of number of SMEs. Then, the municipal government in cooperation with educational institutions provides training and assistance to the majority of housewives to be given skills training in processing milk. The training and mentoring work well until there are many dairy business groups growing in this cluster. They together learn how to entrepreneurship such as in research and develop dairy innovation products, team management in groups and their conflicts, and other challenges. Hence, business groups where it can be said as a container of SMEs get a lot of experience and science valuable in building their entrepreneurial competence. The education gained from the training helped to open the insights of business groups to be creative in interpreting their potential, so that although some groups disbanded. Former executives and members have the initiative to continue the group's business independently. Where the boards and group members have entrepreneurial competence in daring to try new things, innovate, persistent, and never give up in building their business. The description of the process of dairy cluster formation in Cipageran is vertically formed as seen in Figure 2, where initiation of cluster formation is initiated by the local government in collaboration with other quadruple helix elements. An overview of the cluster-based cluster formation process previously described in the Tambunan (2005) study. The difference is the illustration of the process of milk dairy cluster formation is more emphasis on the formation and role of small groups, where each group will form a business unit.

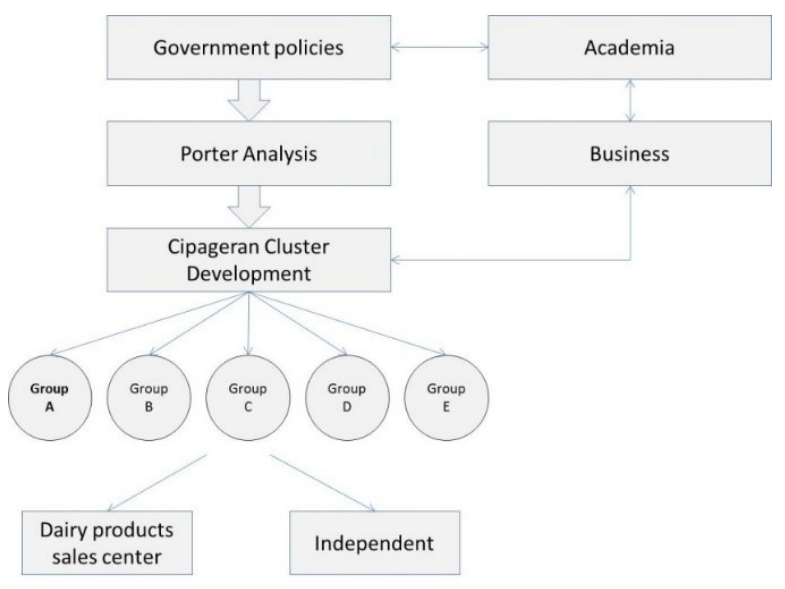

Fig. 2. Model of Dairy Milk's cluster in Cipageran

The formation of this Cipageran milk cluster uses education policy[10]. Where the government cooperates with other quadruple helix makes the curriculum to foster entrepreneurship spirit and to read and learn. The majority of the population has a low level of formal education. Hence, the existence of this business training activities as well as encourage their learning interest. This type of dairy cluster is the same as the chips cluster, which is the active type, where in this cluster involves specific expertise with the use of technology. Expertise in this cluster is in term of caring for cattle to produce quality milk and certain skills in making various dairy products.

\section{Conclusion}

Clustering has different approaches. This is motivated by the motivation in forming the cluster. These two types of clusters have different formation approaches. Where the cluster of chips stands independently and naturally, a dairy cluster stands on the initiation of 
local government policy in developing potential. Although the processes in cluster formation are different, these two clusters have been beneficial in the economy even in small geographic areas. At the very least, cluster formation has encouraged people's purchasing power and ability to innovate in product commercialization. The formation of chips clusters was formed due to successful neighboring motivations that then spread to neighboring surrounding areas. This phenomenon actually provides a positive competition. Although their businesses are the same, they are able to develop different target markets between one SME and another. As discussed earlier, the formation of dairy clusters is formed on the initiation of local governments in collaboration with other quadruple helix elements. The formation of small groups with the output of business units helps in developing the capacity and competence of the participants. Although in the process many participants who resigned or dismissed their business, among them some are back to build business independently armed with knowledge and experience in the group. Same as expressed by Handayani et al., (2012), that the transformation of cluster innovation or business dissolution can occur in various phases in clustered. Because the cluster is a merger of art and science, where in solving the problems needed creativity and good analysis so that clusters can survive and develop.

\section{References}

1. M. Industri, Pertumbuhan Industri Melampui Target. (Media Industri, 2010)

2. J.E. Fensterseifer, J.L. Rastoin. Cluster resources and competitive advantage: A typology of potentially strategic wine cluster resources. International Journal of Wine Business Research, 25(4), pp.267-284, (2013)

3. M. Tieman, Halal clusters. Journal of Islamic Marketing, 6(1), pp.2-21, (2015)

4. N. Reid, M.C. Carroll, and B.W. Smith, Critical Steps in the Cluster Building Process. EcDevelopment, 6(4), pp.44-53. (2007)

5. Kementerian Pemberdayaan Perempuan dan Perlindungan Anak Republik Indonesia, Manual Model Pelaksanaan Kebijakan Industri Rumahan Melalui Cluster Makanan dan Minuman, (2005)

6. L.P. Dana, K.E. Winstone, Wine cluster formation in New Zealand: Operation, evolution and impact. International Journal of Food Science and Technology, 43(12), pp.2177-2190, (2008)

7. M. Najib, A. Kiminami, Innovation, cooperation and business performance. Journal of Agribusiness in Developing and Emerging Economies, 1(1), pp.75-96. (2011)

8. M.K. Mawardi, T. Choi, and N. Perera, The Factors of SME Cluster Developments in a Developing Country: the case of Indonesian clusters. ICSB World Conference Proceedings, pp.1-28. (2011)
9. N.U. Handayani, A. Cakravastia, L. Diawati, and S.N. Bahagia, A conceptual assessment model to identify phase of industrial cluster life cycle in Indonesia. Journal of Industrial Engineering and Management, 5(1), pp.198-228, (2012)

10. E. Popkova, A. Natsubidze, E. Kukina, V. Urodovskikh, E. Ioda, and N. Neustrova, Problems and perspectives of implementation of cluster initiatives in business in developing countries. European Research Studies Journal, 18(3), pp.187-196. (2015)

11. T. Tambunan, Promoting Small and Medium Enterprises with a Clustering Approach: A Policy Experience. Journal of Small Business Management, 43(2), pp.138-154, (2005)

12. A,K. Singh, R.L. Shrivastava, Critical success factors of rice mills located in a cluster. International Journal of Productivity and Performance Management, 62(6), pp.616-633, (2013)

13. S.A.A. Wijaya, Studi peranan klaster industri, hambatan bisnis, dan kepemilikan asing terhadap intensitas kapital di indonesia. AGORA, 3(2), pp.1-5. (2015)

14. L. Aarikka-Stenroos, and T. Lehtimäki, Commercializing a radical innovation: Probing the way to the market. Industrial Marketing Management, 43(8), pp.1372-1384. (2014)

15. Bank Indonesia, Kegiatan Bank Indonesia Dalam Mendukung Ketahanan Pangan Berbasis Klaster Komoditi Unggulan (Panduan Replikasi). (2014)

16. J.W. Creswell, Qualitative Inquiry and Research Design: Choosing Among Five Approaches. California: Sage Publications, Inc. (2007) 